IJLR: International Journal of Law Recontruction

Volume 5, Number 1, April 2021

DOI : http://dx.doi.org/10.26532/ijlr.v5i1.15580

\title{
JURIDICAL REVIEW OF BUILDING RIGHTS EXTENSION ON MANAGEMENT RIGHTS
}

\author{
Herlina Hanum Harahap \\ Muslim Nusantara Al-Washliyah University \\ linahrp4@gmail.com \\ Danial Syah \\ Sumatera Utara Islamic University \\ sh.mhdanialsyah@yahoo.com
}

\begin{abstract}
The term of Building Use Rights on Management Rights was initially for 50 years in accordance with the provisions of Article 35 of Act No. 5 of 1960 but with the existence of Article 29 of Government Regulation Number 27 of 2014 to five 5 years. This clearly results in the issue of legal uncertainty for holders of Building Use Rights over Management Rights. The method used is normative juridical, the results of research obtained based on the analysis carried out can be seen that so far the arrangement for extension of Building Use Rights over Management Rights cannot be separated from the provisions of Article 35 of Act No. 5 of 1960, namely 30 years which can be extended with an approved for 20 years, with the provision of Article 29 of Government Regulation Number 27 of 2014 on Management of State and/or Regional Property, it has clearly changed the length of time granting Building Use Rights over Management Rights, namely for five years which can be extended with government approval. The provisions of Article 29 of Government Regulation Number 27 of 2014 on Management of State and/or Regional Property have resulted in legal certainty issues and can harm the holders of Building Use Rights above management rights so that it is clear that the provisions including Verordnung \& Autonome Satzung have contradicted the provisions.
\end{abstract}

Keywords: Building Use Rights, Justice Relevance, Management Rights.

\section{A. INTRODUCTION}

Earth, water and space including natural resources contained therein are controlled by the state as an organization of power for all the people, as stipulated in Article 2 paragraph (1) of the Basic Agrarian Law as the elaboration of Article 33 paragraph (3) of the 1945 Constitution. It is this state that gave birth to the concept of the Right to Control the State over agrarian resources, which is to achieve the greatest possible prosperity for the people in the sense of nationality, welfare and independence in society 
and an Indonesian constitutional state that is independent, united, sovereign, just and prosperous. ${ }^{1}$

Nowadays it can be known together that the period of use of Building Use Rights is based on Article 35 of Act No. 5 of 1960 on Basic Agrarian Provisions, it is clear that Building Use Rights in Management Rights are only for 30 years which can only be extended for 20 years when The government agreed to this, so that after 50 years the Building Use Rights could not be extended and automatically the Building Use Rights on Management Rights land also could not be extended after the Building Use Rights were declared non-renewable. In its development, this provision changed with the existence of Article 29 of Government Regulation Number 27 of 2014 on Management of State and/or Regional Property. ${ }^{2}$

Provisions regarding land rights are regulated in Act No. 5 of 1960 on Basic Agrarian Principles, or better known as the Basic Agrarian Law. The Basic Agrarian Law was promulgated in LNRI 1960 No. 104 - TLNRI No. 2043, came into force on September 24, 1960. Article 4 paragraph (1) of the Basic Agrarian Law states that on the basis of the right to control the state various rights over the surface of the earth called land, which can be given to and owned by people, are determined either alone or together with other people and legal entities. The land referred to here is land in the juridical sense, namely the right to land. Land rights can be granted to and owned by individuals, a group of people collectively, and legal entities. ${ }^{3}$

Article 29 paragraph (2) Government Regulation Number 27 of 2014 on Management of State and/or Regional Property states explicitly that "the lease period for state or regional property is five years and can be extended". The extension of state or regional property is regulated in Article 29 paragraph (3) of Government Regulation Number 27 of 2014 on Management of State and/or Regional Property.

The state as an organization of power regulates by making regulations, then carrying out the meaning of implementing (use), supplies (reservations) and maintenance of the earth, water and space and the natural resources contained therein. Also to determine and regulate (establish and make regulations) what rights can be developed from the right to control of the country. And then determine and regulate (establish and make rules) how the relationship between a person or legal entity should be with the earth, water and space and the natural resources contained therein. ${ }^{4}$

This change has clearly resulted in injustice to property buyers who stand on Management Rights land. This can be observed in the case of

1 Triadi Kurniawan, Pemberian Hak Guna Bangunan Di Atas Bagian Tanah Hak Pengelolaan, Keadilan Jurnal Fakultas Hukum Universitas Tulang Bawang, Volume 18, No.1, February 2020, page.70-84

2 Dwi Afni Maileni, Kepastian Hukum Terhadap Hak Milik Diatas Hak Pengelolaan Dikota Batam, Jurnal Hukum De'rechtsstaat, Volume 5 No. 1, March 2019, page. 120.

3 Urip Santoso, Hak Guna Bangunan Atas Hak Pengelolaan (Suatu Kajian Perolehan Hak dan Perpanjangan Jangka Waktu), ADIL, Vol. 2 No. 3 December 2011, page.286-306

4 Lovelly Dwina Dahen, Analisis Yuridis Terhadap Hak-Hak Atas Tanah Yang Berada Di Atas Hak Pengelolaan Pelabuhan, Jurnal IImu Hukum, Volume 3, No. 1, 2012, page.1-29 
Mediterania Palace Residence in Kemayoran, East Jakarta. The apartment owned by the property developer Agung Podomoro Group was built on land owned by the State Secretariat Ministry, where the Building Use Rights over the Management Rights expire in 2022. The dilemma of consumers who own property in the apartment only knows about the issue of Building Use Rights over Management Rights buy property in the Mediterania Palace Residence. The term extension of the Building Use Rights on Management Rights is circumvented by changing it to the term "strata title".

Provisions regarding the lease period for state or regional property in its development also have an impact on the owners of Building Use Rights on land under Management Rights. Basically, the provisions of Article 29 Number 27 of 2014 on Management of State and/or Regional Property are contrary to the provisions of Article 35 of Act No. 5 of 1960 on Basic Agrarian Provisions, where Article 35 of Act No. 5 of 1960 on Basic Provisions Agraria states that the HGB can be valid for thirty years and be renewed for another twenty years. So it is clear that there has been a dissynchronization between Act No. 5 of 1960 on Basic Agrarian Provisions and Government Regulation Number 27 of 2014 on Management of State and/or Regional Property.

The discrepancy issue can be seen in the considerations and legal basis of Government Regulation Number 27 of 2014 on Management of State and/or Regional Property does not contain Act No. 5 of 1960 on Basic Agrarian Provisions and Government Regulation Number 40 of 1996 on Use Rights Business, Building Use Rights and Land Use Rights. So that the concept of state or regional property in the form of Management Rights land is contrary to the concept of Management Rights land in Act No. 5 of 1960 on Basic Agrarian Provisions and Government Regulation Number 40 of 1996 on Business Use Rights, Building Use Rights and Land Use Rights. has resulted in violating the mandate of Article 28D paragraph (1) Article 28G paragraph (1) of the 1945 Constitution of the Republic of Indonesia, so it is clear that this issue also violates the First, Second, and Fifth Precepts of Pancasila. In the above case, it can be seen that disharmony has occurred between Das Sollen and Das Sein.

The view above shows clearly that Article 29 paragraph (2) Government Regulation Number 27 of 2014 on Management of State and/or Regional Property is contrary to Act No. 5 of 1960 on Basic Agrarian Provisions and Government Regulation Number 40 of 1996 on Business Use Rights, Building Use Rights and Land Use Rights in terms of the concept of the validity period of the Building Use Rights. This has clearly violated the mandate of Article 28D paragraph (1) Article 28G paragraph (1) of the 1945 Constitution of the Republic of Indonesia, so it is clear that this issue also violates the First, Second and Fifth Precepts of the Pancasila. In the above case, it can be seen that disharmony has occurred between Das Sollen and Das Sein. So that the law is no longer capable of realizing its task which is none other than realizing justice, benefit and order in Indonesian society.

This writing aims to analyze and describe issues related to juridical review of the implementation of extension of building use rights over 
management rights, where problems have occurred due to changes in the length of time to use Management Rights due to the existence of Article 29 paragraph (2) Government Regulation Number 27 of 2014 on Management. State and/or Regional Property.

Based on the existing explanation, this writing aims to further analyze the problem of inequality in the provisions in Article 35 of Act No. 5 of 1960 on Basic Agrarian Provisions with the provisions in Article 29 of Government Regulation Number 27 of 2014 on Management of State and/or Regional Property.

\section{B. RESEARCH METHODS}

The research method used is non-doctrinal where this writing uses legal analysis both from the aspect of grammatical meaning and norms behind legal regulations as well as in terms of law enforcement in society. The approach used is a descriptive analytical approach, which examines the law with a sociological and juridical analytical approach which is then described. ${ }^{5}$

\section{RESULT AND DISCUSSION}

1. Building Use Rights Extension on Management Rights according to Basic Agrarian Law and Government Regulation No. 27 of 2014 on State Property Management

Regulations related to the length of time to use Building Use Rights before the existence of Article 29 Government Regulation Number 27 of 2014 on Management of State and/or Regional Property, are contained in Article 35 of Act No. 5 of 1960 on Basic Regulations on Basic Agrarian Principles of the President of the Republic of Indonesia that states:

a. Right to build is the right to construct and own buildings on land that is not his own, with a maximum period of 30 years.

b. At the request of the right holder and taking into account the needs and condition of the buildings, the period mentioned in paragraph (1) can be extended for a maximum period of 20 years.

c. The right to build can be transferred and transferred to other parties.

Based on the above provisions, it can be clearly seen that the application period for building use rights is 30 years and can be extended to 20 years at the request of the right holder and taking into account the needs and condition of the buildings. So it is clear that the duration of the Building Use Rights according to Article 35 of Act No. 5 of 1960 on Basic Agrarian Basic Regulations for the President of the Republic of Indonesia is for 50 years where the HGB at the beginning of the right is granted for 30 years and can be extended 20 years on the basis of existence request of the right holder and taking into account the need

5 Kornelius Benuf dan Muhamad Azhar, Metodologi Penelitian Hukum sebagai Instrumen Mengurai Permasalahan Hukum Kontemporer, Jurnal Gema Keadilan, Volume 7 Edisi I, June 2020, page. $26-27$ 
and condition of the buildings. ${ }^{6}$

Regulation of Building Use Rights on Land with Management Rights in Government Regulation Number 27 of 2014 on Management of State and/or Regional Property is regulated in Article 29. Article 29 paragraph (2) Government Regulation Number 27 of 2014 on Management of State Property and/or Regions state firmly that "the lease period for state or regional property is five years and can be extended"7

Article 29 paragraph (3) Number 27 of 2014 on Management of State and/or Regional Property which states that: The lease period for state/regional property as meant in paragraph (2) Article 29 can be more than five years, in the event that state/regional property is used for:

a. Cooperation in the infrastructure sector;

b. Activities that take more than five years; and

c. Determined otherwise by law.

Based on the regulation in Article 29 paragraph (3) Government Regulation Number 27 of 2014 on Management of State and/or Regional Property above, it is clear that the extension of Building Use Rights to Management Rights is included in the category of leasing property owned by the state and/or areas where the Right For building purposes, land management rights which include state and/or regional property are no longer 30 years old as regulated in Article 35 of Act No. 5 of 1960 on Basic Agrarian Regulations for the President of the Republic of Indonesia, but for five years.

So it is clear that there has been a change in the old arrangement for granting Building Use Rights over the management rights between Article 35 of Act No. 5 of 1960 on Basic Agrarian Provisions with Article 29 of Government Regulation Number 27 of 2014 on Management of State and/or Regional Property. The following will show the differences between Article 35 of Act No. 5 of 1960 on Basic Agrarian Provisions and Article 29 of Government Regulation Number 27 of 2014 on Management of State and/or Regional Property related to the regulation of Building Use Rights over Management Rights.

Hans Nawiasky stated that the rule of law is a layered system consisting of four major groups, namely: ${ }^{8}$

a. Staatsfundamentalnorm (State Fundamental Norms);

b. Staatsgrundgesetz (Basic Country Rules/Basic Country Rules);

c. Formell Gezets (Formal Law);

d. Verordnung \& Autonome Satzung (Implementing Rules \& Autonomous Rules).

Nawiasky's view is also shared in Act No. 12 of 2011 Jo. Act No. 15 of 2019 On the Formation of Legislative Regulations. This can be seen in Article 2 of Act No. 12 of 2011 Jo. Act No. 15 of 2019 on the Formation

6 Maria S.W. Sumardjono, 2008, Tanah Dalam Perspektif Hak Ekonomi, Sosial dan Budaya, Kompas, Jakarta, page. 280.

7 Yusriyadi, 2010, Industrialisasi Dan Perubahan Fungsi Sosial Hak Milik Atas Tanah, Genta Publhising, Yogyakarta, page. 62

8 Hans Nawiasky, 1948, Allgemeine Rechtslehre als System der rechtlichen Grundbegriffe, Printed-2, Einseideln/Zurich/Koln, Benziger, page. 31 
of Legislative Regulations which states that "Pancasila is the source of all sources of state law".

Then Article 7 of Act No. 12 of 2011 Jo. Act No. 15 of 2019 on the Formation of Laws and Regulations which states that:

a. Types and hierarchy of Legislation consist of:

1) The 1945 Constitution of the Republic of Indonesia;

2) Decree of the People's Consultative Assembly;

3) Laws/Government Regulations in Lieu of Laws;

4) Government regulations;

5) Presidential decree;

6) Provincial Regulation; and

7) Regency/City Regional Regulations.

b. The legal force of Legislation in accordance with the hierarchy as referred to in paragraph (1).

Based on the above view, it is clear that in the legal system in Indonesia the system used is a hierarchy of layered legal regulations, where the highest position is the basic norm or Staatsfundamentalnorm which in the Indonesian legal system is Pancasila, and then Staatsgrundgesetz or basic law in the Indonesian legal system. is the 1945 Constitution of the Republic of Indonesia, then in the third layer, namely Formell Gezets or legislation which in the legal system in Indonesia includes Act No. 5 of 1960 on Basic Agrarian Provisions, which in the last layer is Verordnung \& Autonome Satzung or implementing regulations which in this case include Number 27 of 2014 on Management of State and/or Regional Property.

According to Hans Nawiasky, the norms above must be able to cover the norms that are below them, so Staatsfundamentalnorm must be able to cover Staatsgrundgesetz, Formell Gezets, and Verordnung \& Autonome Satzung, while Staatsgrundgesetz, Formell Gezets, and Verordnung \& Autonome Satzung must be compatible and not opposite and contrary to Staatsfundamentalnorm.

Sociologically, it can be seen that the statement of the affected community from the old provisions on the use of Building Use Rights on Management Rights land as stipulated in Government Regulation Number 27 of 2014. According to Endry as the owner of Building Use Rights over Management Rights located on Jl. Burjamhal Blok A No. 26, Medan, with the existence of Article 29 paragraph (3) Number 27 of 2014 on Management of State and/or Regional Property has clearly resulted in legal uncertainty and legal injustice for him, which Endri admitted that so far, Building Use Rights are above Rights. Land management has been well regulated in the Basic Agrarian Law, ${ }^{9}$ the existence of Article 29 paragraph (3) Government Regulation Number 27 of 2014 on

9 Sausan Yodiniya, Yani Pujiwati, dan Betty Rubiati, Hak Milik Atas Satuan Rumah Susun Untuk Pertokoan Dengan Status Hak Guna Bangunan Di Atas Hak Pengelolaan Dikaitkan Dengan Undang - Undang Nomor 20 Tahun 2011 Tentang Rumah Susun, Acta Diurnal Jurnal Ilmu Hukum Kenotariatan Fakultas Hukum Unpad, Volume 3, Nomor 2, June 2020, page. 242-243. 
Management of State and/or Regional Property has contradicted and is not in accordance with the duration of Building Use Rights over Management Rights, this results in losses, especially economically.

The various problems above show that there needs to be an adjustment in the length of time the use of state property, including land management rights and building use rights. Where should the duration of the Building Use Rights on Management Rights in the provisions of Government Regulation Number 27 of 2014 on Management of State and/or Regional Property as Verordnung \& Autonome Satzung, adjust the provisions as intended in the Formell Gezets. ${ }^{10}$

\section{The Relevance of Justice Value to Implementation of Building Use Rights Extension on Management Rights}

Legal policies regulating use rights over management rights should be able to realize the mandate of the purpose of the state. The goals of the state that depart from the ideals of the nation's people have been summed up in the five principles of Pancasila. So in other words, the implementation of legal politics is based on the five principles of Pancasila, namely God Almighty, Justice and Civilized Humanity, Indonesian Unity. ${ }^{11}$

Democracy led by wisdom of wisdom in deliberation/representation, and social justice for all Indonesian people. Legal politics which is based on the value of One Godhead means that legal politics must be based on divine moral values. Legal politics based on the values of Just and Civilized Humanity means existing legal politics must be able to guarantee respect and protection for human rights in a nondiscriminatory manner. ${ }^{12}$

Legal politics must be based on the value of Indonesian Unity, meaning that legal politics must be able to unite all elements of the nation with all their respective primordial ties. Political law based on populist values led by wisdom in deliberation/representation means that legal politics must be able to create state power that is under the power of the people, ${ }^{13}$ or in other words, legal politics must be able to create a democratic country where the greatest power is in the hands of the people (populist democracy). ${ }^{14}$ Then the last thing is that legal politics must be based on the value of Social Justice for All Indonesians, meaning that legal politics must be able to create a socially just society that is able

10 Muhtadi, Penerapan Teori Hans Kelsen Dalam Tertib Hukum Indonesia, Fiat Justitia Jurnal IImu Hukum Vol. 5 No. 2 September-December 2012, page. 293-294.

11 Ahmad Zubaidi, Landasan Aksiologis Pemikiran Bung Hatta Tentang Demokrasi, Jurnal Filsafat, Vol.21, Nomor 2, August 2011, page.26-27.

12 Ferry Irawan Febriansyah, Keadilan Berdasarkan Pancasila Sebagai Dasar Filosofis Dan Ideologis Bangsa, DiH Jurnal Ilmu Hukum, Volume 13 Nomor 25, February 2017, page. 6-10

13 Erika dan Dewa Gede Sudika Mangku, Politik Hukum Pancasila Dalam Paradigma Nilai-Nilai Sosial Kultural Masyarakat Indonesia, Pandecta, Volume 9. Nomor 1. January 2014, page. 45-47

14 Ibnu Asqori Pohan, Aylia Eka Krisdayanti, dan Dakka Bangun Simanjuntak, Rekonstruksi Pemikiran Ekonomi Kerakyatan Mohammad Hatta, Jurnal Ilmu Politik dan Pemerintahan, Vol. 4 No. 1, November 2018, page. 21-31 
to create justice for the weak community both in the social sector and in the economic sector, so that there is no oppression between power societies. full of marginalized people.

The various values contained in the five principles of Pancasila are then concretized in the objectives of the state which are contained in the fourth paragraph of the creation of the 1945 Constitution of the Republic of Indonesia. The fourth paragraph of the creation of the 1945 Constitution of the Republic of Indonesia states that: ${ }^{15}$

a. Protect the entire nation and all spilled Indonesian blood;

b. Promote the general welfare;

c. Enrich the life of a nation;

d. Participating in world order, based on freedom, eternal peace and social justice.

So it is also clear that legal politics must be based on the four principles contained in the fourth paragraph of the creation of the 1945 Constitution of the Republic of Indonesia. In this regard Mahfud M. D. stated that: ${ }^{16}$ In the context of political law, it is clear that law is a "tool" that works in a certain "legal system" to achieve the "goals" of the state or the "ideals" of the Indonesian people. Therefore, discussion of the politics of national law must be preceded by an affirmation of the objectives of the state.

Based on the opinion of Mahfud M. D., it is clear that Pancasila is the foundation and source of all sources for national legal politics. This is because Pancasila and the introduction of the 1945 Constitution of the Republic of Indonesia contain various ideals of the Indonesian nation which are rechtsidee, namely to create a state capable of creating social justice based on divine moral values, humanity, unity through mutual cooperation instead of democracy through western democracy. In order to make this happen, it is clear that the rule of law of Pancasila is needed. ${ }^{17}$

Based on the various explanations above, it can be seen that the provisions of Article 29 of Government Regulation Number 27 of 2014 on Management of State and/or Regional Property have resulted in legal certainty issues and can harm the holders of building use rights over management rights so that it is clear that the provisions which include Verordnung \& Autonome Satzung has contradicted the provisions of Article 35 of Act No. 5 of 1960 as Formell Gezets, this has also deviated from the mandate of Article 28D paragraph (1) of the 1945 Constitution of the Republic of Indonesia which is Staatsgrundgesetz automatically also contradicts Pancasila as Staatsfundamentalnorm. ${ }^{18}$ This can clearly result in obstruction of domestic economic development due to the

15 Laurensius Arliman S., Kedudukan Lembaga Negara Independen Di Indonesia Untuk Mencapai Tujuan Negara Hukum, Jurnal Kertha Semaya, Vol. 8, No.7 2020, page. 1040

16 Ferry Irawan Febriansyah, Op.cit, page. 17.

17 Adrianus M.Nggoro, Makna Negara Hukum Dalam Perspektif Politik Hukum (Telaah Yuridis Materil Dan Formil), Jurnal Hukum Sehasen, Vol.2 No.2 November 2017, page.36-37.

18 Ahmad Zuhdi Muhdlor, Perkembangan Metodologi Penelitian Hukum, Jurnal Hukum dan Peradilan, Vol. 1, No. 2 2012, page. 200. 
increasing complexity of filing for building use rights over management rights for the needs of business development. ${ }^{19}$

\section{CONCLUSION}

The arrangement for extension of Building Use Rights above Management Rights cannot be separated from the provisions of Article 35 of Act No. 5 of 1960, namely 30 years which can be extended with an approved application for 20 years, with the provision of Article 29 Government Regulation Number 27 of 2014 on Management of Property The State and/or Regions have clearly changed the length of time granting Building Use Rights over Management Rights, namely for five years which can be extended with government approval. The contradiction between these two provisions has also shown disharmony between legal regulations related to the regulation of Building Use Rights over Management Rights; So that the provisions of Article 29 paragraph (2) Government Regulation Number 27 of 2014 on Management of State and/or Regional Property must be adjusted to the provisions of Article 35 of Act No. 5 of 1960 as Formell Gezets which are above it.

\section{BIBLIOGRAPHY}

\section{Books:}

Hans Nawiasky, 1948, Allgemeine Rechtslehre als System der rechtlichen Grundbegriffe, Printed- 2, Einseideln/Zurich/Koln, Benziger;

Maria S.W. Sumardjono, 2008, Tanah Dalam Perspektif Hak Ekonomi, Sosial dan Budaya, Kompas, Jakarta;

Yusriyadi, 2010, Industrialisasi Dan Perubahan Fungsi Sosial Hak Milik Atas Tanah, Genta Publhising, Yogyakarta;

\section{Journals:}

Adrianus M.Nggoro, Makna Negara Hukum Dalam Perspektif Politik Hukum (Telaah Yuridis Materil Dan Formil), Jurnal Hukum Sehasen, Vol.2 No.2 November 2017;

Ahmad Zubaidi, Landasan Aksiologis Pemikiran Bung Hatta Tentang Demokrasi, Jurnal Filsafat Universitas Gadjahmada, Vol.21, Nomor 2, August 2011;

Ahmad Zuhdi Muhdlor, Perkembangan Metodologi Penelitian Hukum, Jurnal Hukum dan Peradilan, Vol. 1, No. 2, 2012;

Cokorda Istri Brami Putri Biya dan Dewa Gde Rudy, Persekutuan Komanditer Sebagai Subjek Pemegang Hak Guna Bangunan Berdasarkan Surat

19 Cokorda Istri Brami Putri Biya dan Dewa Gde Rudy, Persekutuan Komanditer Sebagai Subjek Pemegang Hak Guna Bangunan Berdasarkan Surat Edaran Menteri ATR/BPN Nomor 2/SEHT.02.01/VI/2019, Acta Comitas, Jurnal Hukum, Vol. 05 No 01 April 2020, page.6. 
Edaran Menteri ATR/BPN Nomor 2/SE-HT.02.01/VI/2019, Acta Comitas, Jurnal Hukum, Vol. 05 No 01 April 2020;

Dwi Afni Maileni, Kepastian Hukum Terhadap Hak Milik Diatas Hak Pengelolaan Dikota Batam, Jurnal Hukum De'rechtsstaat, Volume 5 No. 1, March 2019;

Erika dan Dewa Gede Sudika Mangku, Politik Hukum Pancasila Dalam Paradigma Nilai-Nilai Sosial Kultural Masyarakat Indonesia, Pandecta, Volume 9 Nomor 1 January 2014;

Ferry Irawan Febriansyah, Keadilan Berdasarkan Pancasila Sebagai Dasar Filosofis Dan Ideologis Bangsa, DiH Jurnal IImu Hukum, Volume 13 Nomor 25 February 2017;

Ibnu Asqori Pohan, Aylia Eka Krisdayanti, dan Dakka Bangun Simanjuntak, Rekonstruksi Pemikiran Ekonomi Kerakyatan Mohammad Hatta, Jurnal Ilmu Politik dan Pemerintahan, Vol. 4 No. 1, November 2018;

Kornelius Benuf dan Muhamad Azhar, Metodologi Penelitian Hukum sebagai Instrumen Mengurai Permasalahan Hukum Kontemporer, Jurnal Gema Keadilan, Volume 7 Edisi I, June 2020,

Laurensius Arliman S., Kedudukan Lembaga Negara Independen Di Indonesia Untuk Mencapai Tujuan Negara Hukum, Jurnal Kertha Semaya, Vol. 8, No.7 Tahun 2020;

Lovelly Dwina Dahen, Analisis Yuridis Terhadap Hak-Hak Atas Tanah Yang Berada Di Atas Hak Pengelolaan Pelabuhan, Jurnal Ilmu Hukum, Volume 3 No. 1 Tahun 2012;

Muhtadi, Penerapan Teori Hans Kelsen Dalam Tertib Hukum Indonesia, Fiat Justitia Jurnal IImu Hukum Vol. 5 No. 2 September-December 2012,

Sausan Yodiniya, Yani Pujiwati, dan Betty Rubiati, Hak Milik Atas Satuan Rumah Susun Untuk Pertokoan Dengan Status Hak Guna Bangunan Di Atas Hak Pengelolaan Dikaitkan Dengan Undang Undang Nomor 20 Tahun 2011 Tentang Rumah Susun, Acta Diurnal Jurnal IImu Hukum Kenotariatan Fakultas Hukum Unpad, Volume 3, Nomor 2, June 2020;

Triadi Kurniawan, Pemberian Hak Guna Bangunan Di Atas Bagian Tanah Hak Pengelolaan, Keadilan Jurnal Fakultas Hukum Universitas Tulang Bawang, Volume 18. No. 1 February/2020;

Urip Santoso, Hak Guna Bangunan Atas Hak Pengelolaan (Suatu Kajian Perolehan Hak dan Perpanjangan Jangka Waktu), ADIL : Jurnal Hukum, Vol. 2 No. 3 December 2011. 